\title{
Employees on Corporate Boards
}

\author{
Tom Berglund* \\ Hanken School of Economics \\ Martin Holmén \\ University of Gothenburg
}

Employees in Swedish firms have the legal right to be represented on the company board. However, in a considerable share of Swedish listed firms, this option is not exercised. This paper asks why that is the case. We use a simple framework, based on rational choice by individual employees. Our sample consists of 226 listed non-financial Swedish firms in 2001-2007. The results are in line with our predictions. Employee board representation does not impact firm performance, neither positively nor negatively. The main driver of employee board representation is the number of eligible employees. Furthermore, employee board representation decreases with firm risk, slow growth, and internationalization. We conclude that when the law grants the right for employees to be represented on the board a simple model based on individual utility maximization provides an explanation for why the right is used in some firms and not in others. (JEL: G34, J53)

Keywords: employee representation; board composition; dependent directors; firm performance; corporate governance

Article history: Received: 14 March 2016, Received in final revised form: 14 September 2016, Accepted: 11 November 2016, Available online: 22 February 2017

\footnotetext{
* Corresponding author: Tom Berglund, Economics Department, Hanken School of Economics, Arkadiagatan 22, PB 479, 00100 Helsinki, Finland. Phone: + 358403521345. E-mail: berglund@hanken.fi. Comments received when presenting earlier versions of this paper, as well as in the refereeing process for this journal, are gratefully acknowledged, as is the excellent research assistance by Rakesh Rana at the University of Gothenburg and proof-reading by Debbie Axlid. Financial support by VINNOVA (grant 2010-02449 Holmen) is gratefully acknowledged.
}

(Multinational Finance Journal, 2016, vol. 20, no. 3, pp. 237-271)

(C) Multinational Finance Society, a nonprofit corporation. All rights reserved. DOI: $10.17578 / 20-3-2$ 


\section{Introduction}

The right to board level employee representation $(B L E R)$ in Sweden is granted by law. However, in a majority of listed firms, the employees choose not to exercise this right. This paper investigates whether differences in firm characteristics explain why employees choose to be represented on some corporate boards but not others.

If $B L E R$ were beneficial for firm performance, as argued by e.g. Blair and Roe (1999), we would expect to see few firms where $B L E R$ is not implemented. If on the other hand $B L E R$ were detrimental to firm performance, as argued by e.g. Jensen and Meckling (1979), we would expect few firms where employees insist on it. Based on the insight in Coase's theorem the parties involved are likely to agree on value-maximizing arrangements.

In line with this observation previous empirical $B L E R$ research covering the relation between $B L E R$ and firm performance has produced contradictory results. For instance Fauver and Fuerst (2006) and Ginglinger, Megginson, and Waxin (2011) find a positive relation between $B L E R$ and firm performance in Germany and France, respectively, while for example Gorton and Schmid (2004) and Bøhren and Strøm (2010), document a negative relation between BLER and firm performance in Germany and Norway, respectively.

This paper takes the findings that BLER in general doesn't have a clear cut implication on firm performance as the point of departure. We start by testing whether this conjecture is consistent with our data. We then go on to explain why some firms have opted for $B L E R$ why others have not by developing and testing a simple framework based on rational choice by eligible employees. According to the Swedish Codetermination Act the employee representative must be employed by the firm, i.e. BLER requires the presence of at least one employee who perceives the expected benefits from being on the board to exceed the expected costs. Since employee representatives are not entitled to compensation for sitting on the board (except for meeting fees), the direct economic incentives for serving on the board are weak. Thus, the perceived expected benefits of serving on the board must be more subtle.

We use a sample of 226 Swedish firms 2001-2007 and OLS and treatment effect models and find that there is no statistically significant relation between $B L E R$ and firm performance. If $B L E R$ is unrelated to firm performance, there is no compelling economic argument, neither in favor nor against $B L E R$. In other words $B L E R$ will not produce 
economic rents that (at least in principle) could be shared by shareholders and employees by choosing one rather than the other option.

Based on the simplifying assumption of independent individual utility maximization by employees, we develop two hypotheses about the presence or absence of $B L E R$ in individual firms. Since $B L E R$ requires that some employees are willing to serve on the board, the first hypothesis is that the likelihood of BLER increases in a non-linear way with the number of employees. The second hypothesis is based on individual employees' expected personal costs and benefits from sitting on the board. The benefits are probably related to career concerns and prestige. The expected costs should be higher in firms where board work is more demanding, which is likely in riskier and less rapidly growing firms. Board work should also be more demanding in firms with more international operations. Thus, the second hypothesis is that the likelihood of $B L E R$ decreases with firm risk, slow growth, and internationalization. We find empirical support for both hypotheses.

Finally, we investigate whether BLER is related to board decisions regarding CEO pay and CEO dismissals. We find that BLER is positively related to both CEO fixed pay and bonuses and that the performance-CEO dismissal sensitivity is stronger in BLER than in non- $B L E R$ firms.

This paper complements the governance literature on the effect of employee representation on firm performance and how created value is distributed among employees and stakeholders. It also adds to our understanding of which firm-specific features make BLER less and more attractive to employees. This is in contrast to previous literature that mainly analyzes the effect of $B L E R$ on firm performance once $B L E R$ is in place.

Blair (1995 and 1998), Blair and Roe (1999), Becht, Bolton and Roell (2003), Freeman and Reed (1983), and Osterloh and Frey (2006) argue that an important favorable aspect of $B L E R$ is that it provides employees with stronger incentives to invest in firm-specific human capital. An employee who is a board member probably has to invest in firm-specific human capital, but this does not imply that $B L E R$, once in place, motivates employees in general to invest in firm-specific human capital.

Our analysis is also related to the organizational psychology literature on employee motivation. Need-motive-value research focuses on determinants of individual behavior in terms of, e.g., equity and justice theories (Kanfer, 1990). Employee motivation might increase 
with $B L E R$ due to equity and justice considerations. Our analysis is related to employee motivation to sit on the board, which again is different from increased work motivation among employees once $B L E R$ is in place.

Another reason proposed in the literature for $B L E R$ to have a positive impact on firm performance is that $B L E R$ makes the board better aware of prevailing sentiments within the workforce and thus facilitates fine tuning of firm policy in a way that will eliminate friction between top management and the workers (see, e.g., Feuver and Fuerst, 2006; Levine and Tyson, 1990). However, critical voices have argued that employee representation could make the top managers and key owners more likely to collude on important issues and to settle them in informal meetings well before the decisions are formally made by the board (Roe, 2003; p. 75). If so, the governance function in the firm would obviously suffer and thus reduce the attractiveness of the firm's shares to small investors in the stock market. Our results relating to higher CEO pay in combination with stronger performance sensitivity of CEO dismissals in BLER firms suggest that the governance function does not necessarily suffer due to BLER (see Weisbach, 1988).

Jensen and Meckling (1979) point out that we do not observe voluntarily chosen $B L E R$ in the USA even if $B L E R$ is allowed. They argue that $B L E R$ contributes to more cumbersome decision making and thus harms performance, and, above all, reduces the market's valuation of the firm, since investors perceive that it makes the management more willing to sacrifice shareholder value for the benefit of employees. In particular, according to Jensen and Meckling (1979) BLER will make required painful restructuring more difficult since employee representatives on the board tend to consider it their duty to resist measures that will require lay-offs.

Garcia-Castro and Aguilera (2015) analyze the relationship between stakeholder theory and the distribution of firms' value creation. They argue that value appropriation by one stakeholder can have a negative, neutral, or positive effect on the total value created by the firm. Thus, based on their arguments, BLER might make it possible for employees to appropriate firm value without it being to the detriment of shareholders, which is in line with our results that BLER does not affect shareholder return or value.

Next, we will outline earlier empirical literature. Our framework and hypotheses are presented in section III. We then we go on to describe the data and define the variables used in the empirical analysis. Section $\mathrm{V}$ first analyzes the relation between $B L E R$ and firm performance in our 
sample of firms and then goes on to estimate to what extent our simple framework based on rational choice by eligible employees helps in explaining the presence or absence of $B L E R$ in individual firms. Section VI puts the results in perspective and concludes the paper.

\section{Earlier Empirical Literature}

$B L E R$ is not a recent phenomenon. It has been implemented in a variety of forms in several countries. In Germany it was introduced in the strategically important coal and steel industries already in 1951, and its reach was expanded to other large German firms in the Codetermination Act of 1976. BLER is not restricted to Germany, however. According to Conchon (2011; p. 11), in "17 out of the 27 European Member States plus Norway, employees are granted the right to be represented on the board of directors or the supervisory board with decision making powers." Jackson (2005) gives an overview of BLER in OECD countries and documents that $B L E R$ is more common than usually believed.

From the beginning, BLER has largely been a political issue supported by the left, represented mostly by social democrats, who have seen it as a way to protect workers' rights, and opposed by conservatives, who have seen it as limiting the freedom of choice for entrepreneurs. Given this set-up, there are naturally conflicting views on whether $B L E R$ is value increasing or value destroying.

The empirical research conducted to date fails to give convincing support for either of the above views. Some studies point to a favorable impact of $B L E R$ while other studies find the opposite, and some find no relationship at all. Tellingly, in a survey of ten empirical studies on the relationship between BLER and company performance in Germany, three find a positive relationship, three find a negative relationship, and four find no relationship (Conchon, 2011; table 2, p 16-17). Garcia-Castro, Arino, and Canela (2010) argue that some of the conflicting empirical evidence concerning the relation between stakeholder interests theory and shareholder value maximization is due to endogeneity problems. Baums and Frick (1999) use an event study approach to investigate how the stock market reacts to new laws and court decisions about German codetermination. They find that the stock market does not react negatively to such news but note that this may be due to the laws and court decisions being anticipated by the market.

The impact of $B L E R$ has also been studied in a number of countries other than Germany. Ginglinger, Megginson, and Waxin (2011) find 
weak support for a positive impact of BLER in French firms in 19982008 , for cases where the representation is connected to employee share ownership. Bøhren and Strøm (2010), on the other hand, find a significantly negative impact of employee board members on both firm valuation and firm performance in Norway in data covering the period 1989-2002.

As for studies on Swedish data, Levinson (2001, p.273), in an article highly sympathetic to $B L E R$, concludes: "The present findings of the study suggest that employee representatives play a rather peripheral role in board activities, particularly when it comes to bringing up problems for discussion and initiating solutions." Similarly, analyzing Danish, Norwegian, and Swedish data from the period 2001-2009, Gregoric et al. (2013) find no relationship between $B L E R$ and firm performance and market valuation, respectively.

\section{Framework and Hypotheses}

Sweden has a one-tier board structure. Corporate boards that consist of non-executive board members play an important role in Swedish corporate governance. ${ }^{1}$ By Swedish law since 1973, if a company has at least $25(1,000)$ employees in a fiscal year, employees have the right to claim 2 (3) employee representatives on the board in the subsequent year. The two-employee minimum is most likely due to the well-known difficulties for a single individual to stand up to group pressure in critical situations.

In addition the law states that employee board representatives can never constitute a majority of the board. In firms with fewer than 25 employees, employees are not entitled to board level representation. The employee representatives on the board must be employed by the company. This means that the population of eligible candidates is strictly limited by the size of the firm. The decision to exercise the right to board representation is made by a local employee organization that is bound by a collective agreement with the company. The employee representatives have the full rights and responsibilities of normal board members but are not allowed to participate in decisions related to general employment conditions for employees. Their votes bear the

1. For a detailed description of Swedish corporate governance, see Lekvall et al. (2014). For a case based study of Nordic board work, see Sjöstrand et al. (2016). 
same weight (one vote per member) as the board members elected by the shareholders. In most firms, employee representatives do not receive a regular compensation for being board members, yet they may be entitled to compensation for board meetings attended.

The Swedish employee representation law captures the simple fact that in a smaller firm it is more difficult to find employees with an interest in serving on the company board. To formalize this, let us simplify by assuming that all employees are equally likely to be interested in a board membership and denote this probability $P$. If all $\mathrm{n}$ employees in the firm independently decide whether they are interested in becoming a board member, the likelihood that there will be two persons who are willing to serve on the board is:

$$
1-F(1 ; n, P)
$$

where $F$ is the cumulative distribution function for the binomial probability distribution. The intuition of equation 1 is that there will be at least two persons among $\mathrm{n}$ employees who are willing to serve on the board unless at most one person is willing. Applying the binomial distribution, the probability that at most one person is willing to serve on the board is given by $F(1 ; n, P)$.

For at least three persons among $\mathrm{n}$ employees to be willing to serve on the board, the expression becomes:

$$
1-F(2 ; n, P)
$$

i.e., the complement to the cases where zero, one, or two employees are willing to serve on the board.

For instance, if a randomly chosen employee is assumed to be willing to serve on the board with a probability of $0.1 \%$, the likelihoods that at least two and at least three employees are willing to serve on the board are shown as functions of the number of employees in the firm in figure 1 .

As can be seen from the figure, the relationship is highly non-linear with a convergence toward one as firm size grows. The non-linear relationship means that the marginal impact of additional employees on the probability of finding enough employees willing to be board members normally decreases with the number of employees. Adding one employee will have a smaller impact on the likelihood of being able 


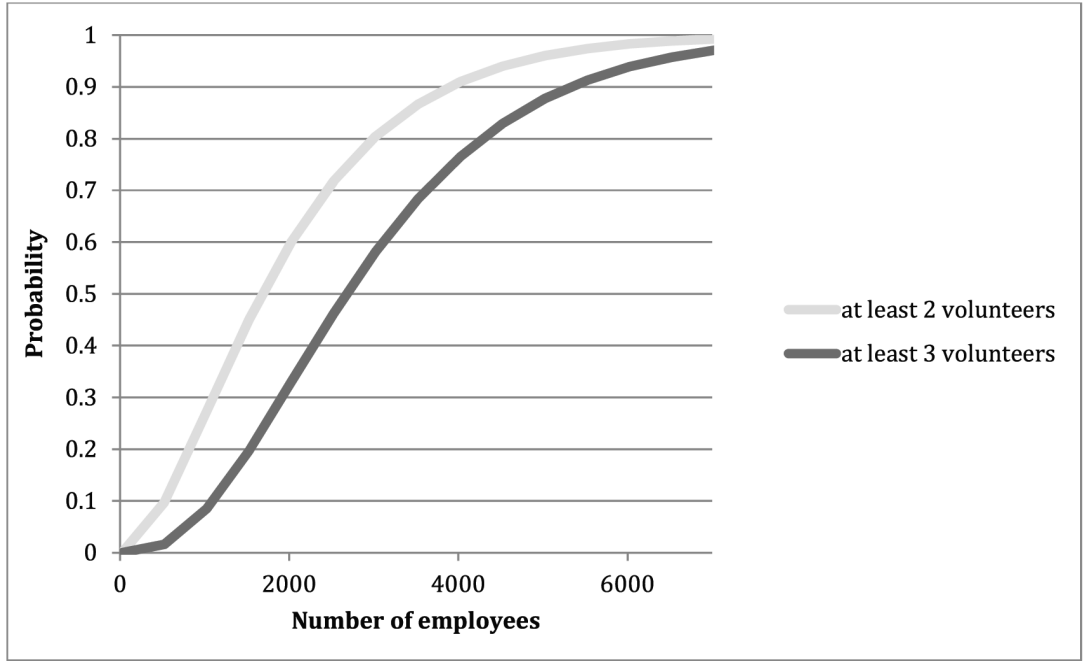

FIGURE 1.- Probability of finding employee members for the board by firm size.

Note: The relationship between the probability of finding at least two/at least three employees willing to serve on the company board and the size of the company measured in number of employees. For this graph, the likelihood that a randomly picked employee is willing to serve on the board is assumed to be $0.1 \%$.

to fill all available board seats in a firm with 100,000 employees than in a firm with 1,000 employees. Obviously the above graph is based on very crude simplifications, perhaps the most important one being that employees decide on whether they are willing to serve on the board independently of each other. However, the non-linearity in the relationship between firm size and likelihood of finding willing persons to serve on the board is likely to carry over to a more realistic setting. When comparing the two graphs for firms with fewer than 1,000 employees, it is also apparent that restricting the number of board seats to two can be seen as a realistic assessment of the likelihood of being able to find interested persons for the job. In more general terms, we expect the following to hold:

Hypothesis 1: There exists a positive non-linear relation between $B L E R$ and the number of employees in the firm.

Systematic factors that will make individuals more (less) willing to 
serve on the board should cause an upward (a downward) shift in the above curves. Since compensation for board work is not relevant for employee representatives, and any impact on expected future compensation in the form of more attractive job offerings is difficult to assess, we focus on factors that are likely to reduce the attractiveness of board membership from an employee's point of view.

First, although prestige in the eyes of fellow employees for being in a position to take part in important decisions is likely to constitute an advantage to some, the position may also create some envy among colleagues, which could tip the scale in the other direction. Most importantly, though, if the firm is doing poorly, part of the blame may be directed to the employee representatives on the board even if they personally have little influence on the causes of the trouble. Thus, board membership will be less attractive if the firm is considered more risky, i.e., if it is more likely that the firm will perform poorly for one reason or another.

Second, board meetings may constitute a forum where an ambitious individual may expect to be able to further her or his career by exhibiting deep knowledge and good judgement on issues that are central to the business development of the firm. Since career opportunities will depend on whether the firm is doing well and expanding or is merely struggling to survive, this motive should be substantially weaker in a slowly growing firm than in a more rapidly expanding firm.

Third, board work will be more demanding and therefore less attractive in a more international firm, since this exposes the firm to more competition and therefore increases the likelihood of poor firm performance. Furthermore, board meetings are held in English, which is not the first language of a vast majority of Swedes.

These arguments are the basis for our second hypothesis.

Hypothesis 2: The likelihood of BLER decreases in firms with i) high risk, ii) slow growth, and iii) more international operations.

\section{Data}

\section{A. Sample}

We use a sample of 226 listed non-financial Swedish firms. Our sample 
period is 2001-2007 and the number of firm years is 1,627. On average, we have 156 firms per year. Since the average number of firms on the Stockholm Stock Exchange during the period is 265, our sample represents roughly 60 percent of Swedish listed firms. The market value of the firms in the sample also represents roughly 60 percent of the Stockholm Stock Exchange market capitalization. Our sample represents more than 75 percent of the market capitalization of non-financial firms.

Accounting data, stock market data, and industry classification are collected from Thomson's Datastream. Information about board characteristics, e.g., employee representation, is collected from Sundin and Sundqvist (2001-2002) and Fristedt and Sundqvist's (2003-2007) Directors and Auditors in Sweden's Largest Companies. Ownership data are collected from Sundin and Sundqvist (2001-2002), Fristedt, Sundin and Sundqvist (2003), and Fristedt and Sundqvist's (2004-2007) Owners and Power in Sweden's Listed Companies. Annual reports are used to collect data on the number of employees in the firm.

\section{B. Variables}

Our analysis focuses on whether employees have exercised the option to be represented on the board or not. We define an indicator variable $B L E R$ that is equal to one if employees are represented on the board, and zero otherwise. We observe changes in BLER in only 17 firm years, i.e., roughly $1 \%$ of the sample years. Thus, if the employees are represented on the board, it tends to stay that way, and the same holds if they are not. The 17 changes in BLER are split roughly evenly between introductions and terminations of employee board representation.

We searched in annual reports for comments relating to introductions and terminations of $B L E R$. We were only able to find two such comments. One was just a statement that the employees had nominated three candidates. The other comment was from a holding company and stated that employees had chosen to be represented in the main portfolio firm instead of on the board of the holding company.

Since there is very little variation in $B L E R$, in most tests we average this and all other variables over the sample years. BLER and the other dummy variables are set to one (zero) if the average is above (below) 0.5 . With these definitions, 106 firms (47 percent) are classified as having employee board representation. 
In 48 firm years, there is only one employee representative on the board when there could have been two or three. In 44 firm years, there are only two employee representatives when there could have been three, i.e., the firms have more than 1,000 employees. These observations appear to be consistent with our conjecture that a crucial determinant of $B L E R$ is finding employees who are interested in sitting on the board.

For the tests of the relation between employee board representation and firm value and performance, respectively, we focus on three variables. First, Tobin's q is used as a proxy for the market's valuation of the firm. Tobin's q is defined as the sum of the market value of equity and the book value of debt divided by the book value of total assets. Second, return on assets $(R O A)$ is used as a proxy for firm performance. $R O A 1$ is defined as the firm's earnings before interest, taxes, and depreciation (EBITD) divided by total assets. ROA2 is defined as the firm's net income divided by total assets. Anderson and Reeb (2003) use the same definitions of ROA.

For the firm valuation and performance analysis, we define a number of independent control variables. Firm size (FIRMSIZE) is defined as the value of total assets in thousand SEK. The firm's capital structure is estimated as long-term debt divided by the book value of equity (DEBT_EQUITY). We include the total investments divided by total sales (INV_SALES) as a proxy for the firm's growth opportunities and the stock market volatility (STOCKVOL) of the firm's share as a proxy for firm risk. Our volatility measure STOCKVOL is the standard deviation of the daily closing stock price changes multiplied by the square root of 252, where 252 is the average number of trading days in a year. In order to control for firm maturity, we include firm age (FIRMAGE).

In the analysis of the likelihood of $B L E R$, we first focus on the number of employees. The variable EMPLOYEES is the number of employees in the firm as reported in the annual report. Our first hypothesis is that employee board representation increases with EMPLOYEES and that this relation is non-linear.

Our second hypothesis is that employee board representation decreases with firm risk, slow growth, and international operations. We define four variables to capture these characteristics.

The first two variables are proxies for risk. The first risk variable is the volatility of the firm's stock (STOCKVOL). The second risk variable is the volatility in the number of firm employees. EMPVOL is defined 


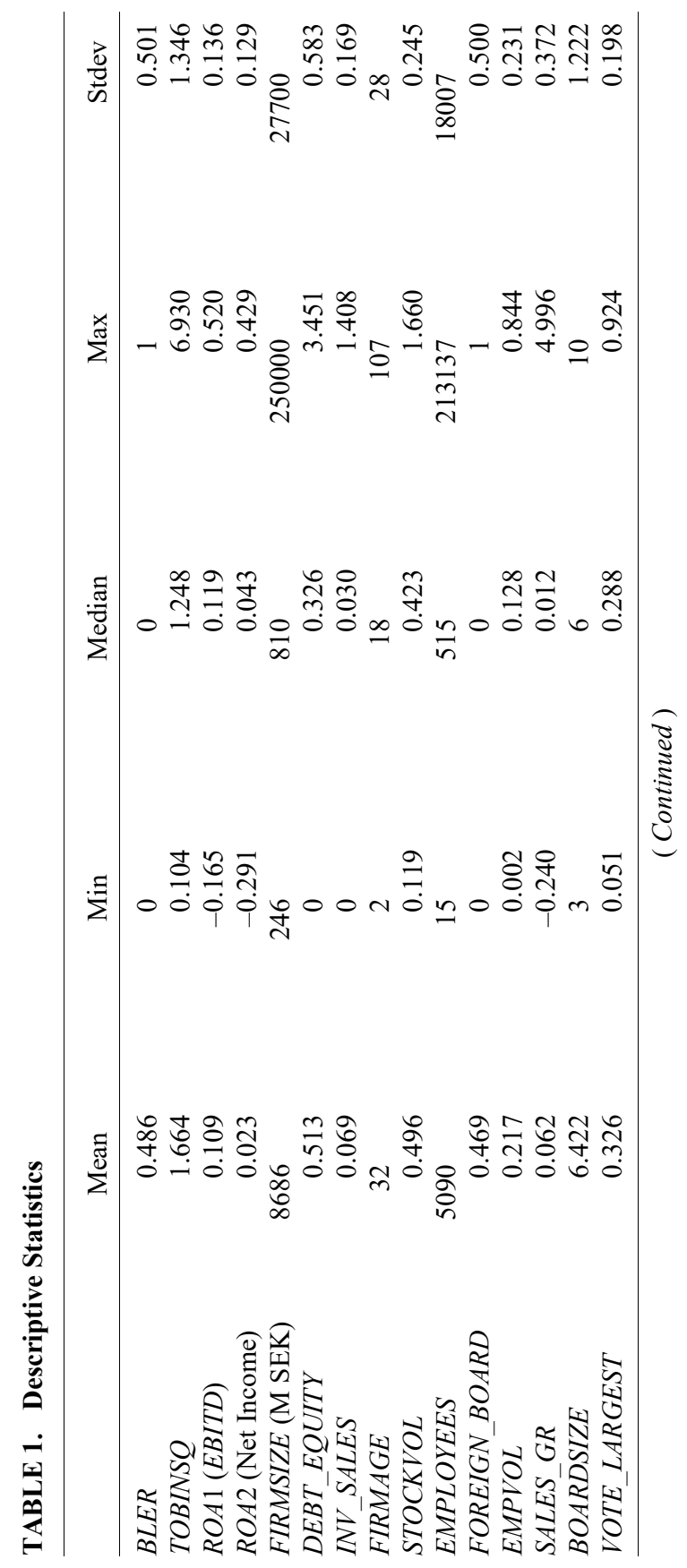




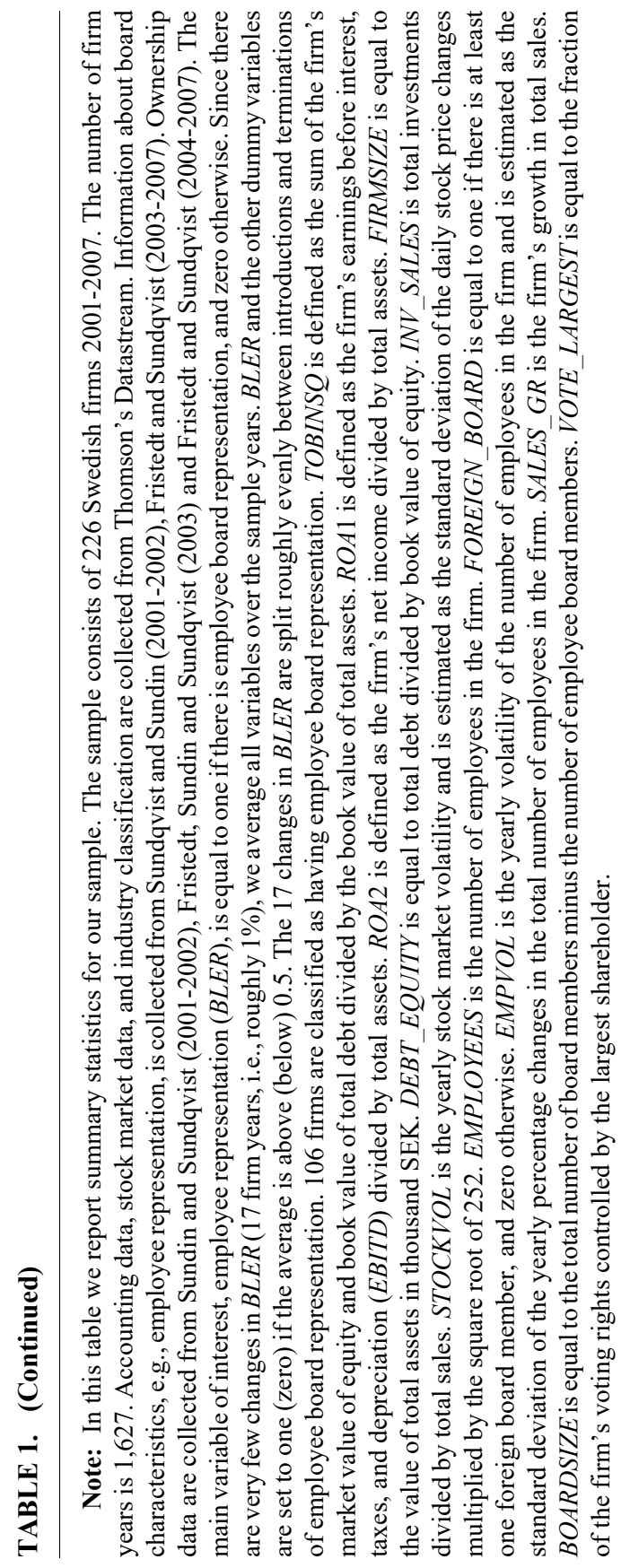




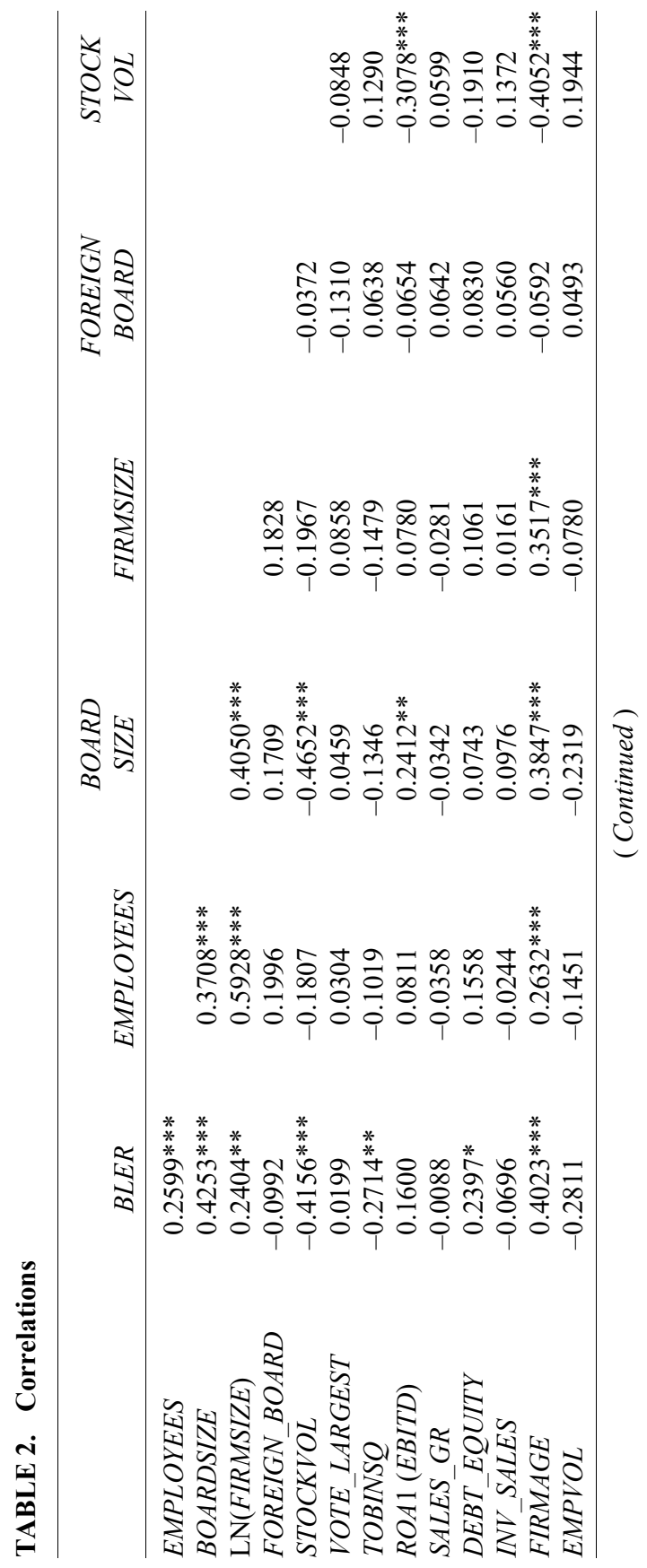




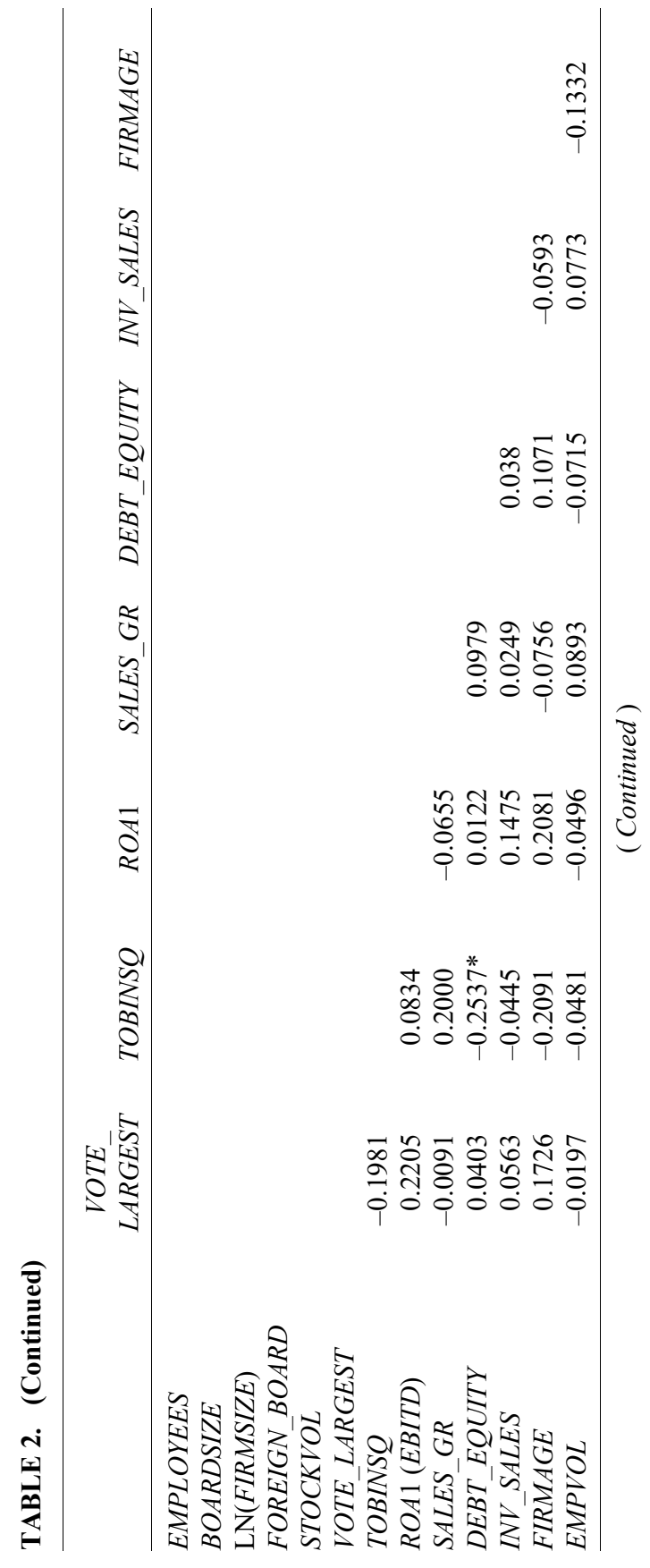




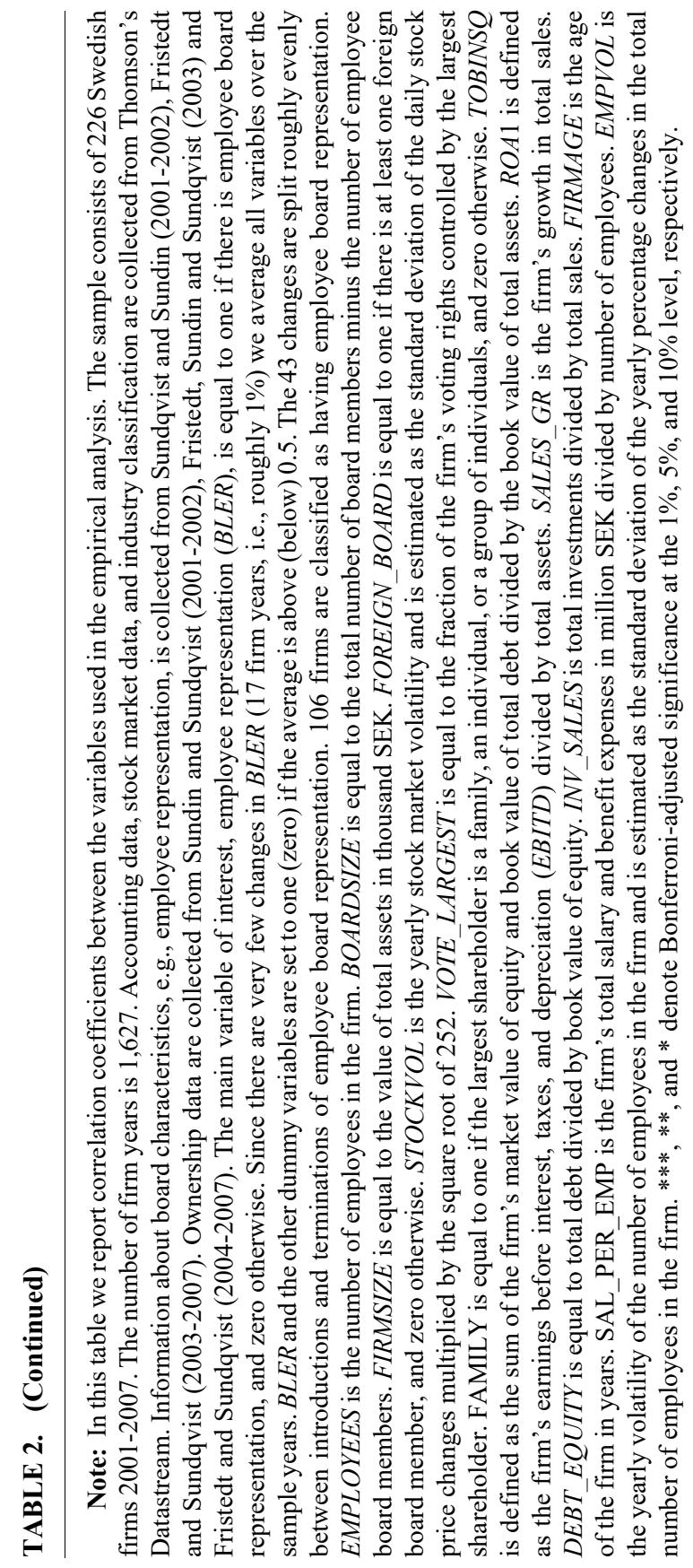


as the standard deviation of the yearly percentage changes in the total number of employees in the firm. If the firm has to lay off people, the employees may partly blame the employee representatives on the board. It is of course expectations about the negative movements in the number of employees that should be of most importance. We argue that the volatility in the number of employees better captures the ex-ante expectations about potential layoffs, while an actual decline in the number of employees is an ex-post outcome.

The third variable, firm growth, is measured by the growth of total sales (SALES_GR). More rapid growth will increase the potential benefits of board work for an employee and therefore increase the likelihood of $B L E R$. The fourth variable is a dummy variable for foreign board members (FOREIGN_BOARD). Firms with foreign board members tend to be more exposed to international competition, making board work more demanding. Causality may also be reversed, i.e., foreign board professionals may shun firms with active local employee representation.

For the analysis of the likelihood of employee board representation, we define two additional control variables. The first is BOARDSIZE, which is defined as the number of board members excluding any employee representatives. While the employees have the right to either two or three board members, the shareholders can reduce their influence on the board by increasing the number of other board members (Thomsen, Rose and Kronborg, 2016). The second is the largest shareholder's voting rights in the firm (VOTE_LARGEST). Employees should find it easier to negotiate with a dominating shareholder than with dispersed shareholders (see Högfeldt, 2005). We therefore expect a positive correlation between employee board representation and VOTE LARGEST.

Finally, in order to control for industry effects, we construct nine industry dummies based on the first digit of the firms' main industry code.

\section{Descriptive statistics}

Table 1 reports descriptive statistics for the sample. The median firm i) has a Tobin's q of 1.248 , ii) generates $R O A 1(R O A 2)$ equal to 0.119 $(0.043)$, iii) has total assets worth SEK 810 million, iv) finances $32.6 \%$ of the assets through debt, v) invests an amount equal to 3 percent of total sales, vi) is 18 years old, vii) has a stock price (employee) volatility of 42.3 (12.8) percent, viii) has 515 employees and zero foreign board members, ix) has a sales growth of 1.2 percent, $x$ ) has six board 
members (excluding employee representatives), and xi) has a dominating shareholder with 28.8 percent of the voting rights.

Table 2 reports pair-wise correlation coefficients and Bonferroni-adjusted significance levels for the variables. Employee board representation is positively (negatively) and strongly correlated with number of employees, board size, and firm age (stock market volatility). Firm size is highly correlated with number of employees, board size, and firm age.

\section{Results}

\section{A. Valuation and performance}

When analyzing the impact of employee board representation on firm value and performance, we first use OLS regressions. Second, in order to control for the fact that employees endogenously decide whether to be represented on the board or not, we run treatment effect models. Garcia-Castro, Arino, and Canela (2010) show how endogeneity issues can affect the estimated relation between firms' social performance and financial performance. Treatment effect models have been used by, e.g., Villalonga and Amit (2006) when investigating the endogenous relation between family ownership and firm performance.

The treatment effect model considers the effect of an endogenously chosen binary treatment - the employee board representation dummy on another endogenous continuous variable, conditional on two sets of independent variables. The main regression equation explains the continuous dependent variable, $\mathrm{y}$, with the BLER dummy and a set of control variables.

$$
\begin{aligned}
y_{i}= & \alpha+\beta_{1} \text { BLER }_{i}+\beta_{2} \ln \left(\text { FIRMSIZE }_{i}\right)+\beta_{3} \text { DEBT_EQUITY }_{i} \\
& +\beta_{4} I N I_{-} S A L E S_{i}+\beta_{5} \ln \left(\text { FIRMAGE }_{i}\right) \\
& +\beta_{6} \text { STOCKVOL }_{i}+\sum_{j=1}^{9} \gamma_{j} \text { Industry }_{j}+\varepsilon_{i}
\end{aligned}
$$

In this equation $B L E R_{i}$, the treatment, is modeled as the outcome of an unobserved latent variable, $B L E R_{i}^{*}$, and $y_{i}$ represents i) TOBINS_Q, ii) 
$R O A 1$, and iii) $R O A 2$, respectively. $B L E R_{i}^{*}$ is estimated as a function of the number of board members excluding employee board representatives. Since the employees have the right to either two or three board members, the shareholders can reduce their influence on the board by increasing the number of other board members. Board size is also the variable that has the strongest correlation with $B L E R$ in our sample (see table 2). All models are estimated with maximum likelihood and reported with heteroscedasticity-corrected z-values in parentheses (White, 1980). Estimating the treatment effect models with the two-step Heckman procedure generates similar results.

The results are reported in table 3. In models 1 and 2, we report the results for Tobin's q estimated with OLS and a treatment effect model, respectively. $B L E R$ is insignificant in both models. In the OLS estimation, DEBT_EQUITY is negative and significant. However, in the treatment effect model, DEBT_EQUITY is insignificant. All the other variables are insignificant in models 1 and 2.

In models 3 and 4 (5 and 6), we report the results for $R O A 1$ (ROA2). Again, $B L E R$ is insignificant in all estimated models. Thus, in line with the inconclusive results for Germany reported by Conchon (2011) and the insignificant results for Scandinavia reported in Gregoric et al. (2013), we do not find a significant relation between BLER and firm performance and value.

The only significant variable is firm size, which is positively significant in all models. During our sample period, several smaller firms in information technology, biotech, and other high-tech industries were struggling in the aftermath of the dot-com bubble and this is not captured completely by the industry dummies. Thus, the positive relation between performance and firm size is mainly driven by poorly performing small firms and not by well-performing large firms.

\section{B. Likelihood of Board Level Employee Representation}

We now turn to the analysis of the presence or absence of $B L E R$ in individual firms. Our first hypothesis is that the likelihood of $B L E R$ increases with the number of employees. Strictly taken, this should be the number of domestic employees in the firm. Using the total number of employees will potentially produce a bias towards insignificance in our results. Furthermore, this relation should be non-linear (see figure $1)$. We therefore include the number of employees expressed in thousands (EMPLOYEES1000) and its squared term in a probit 


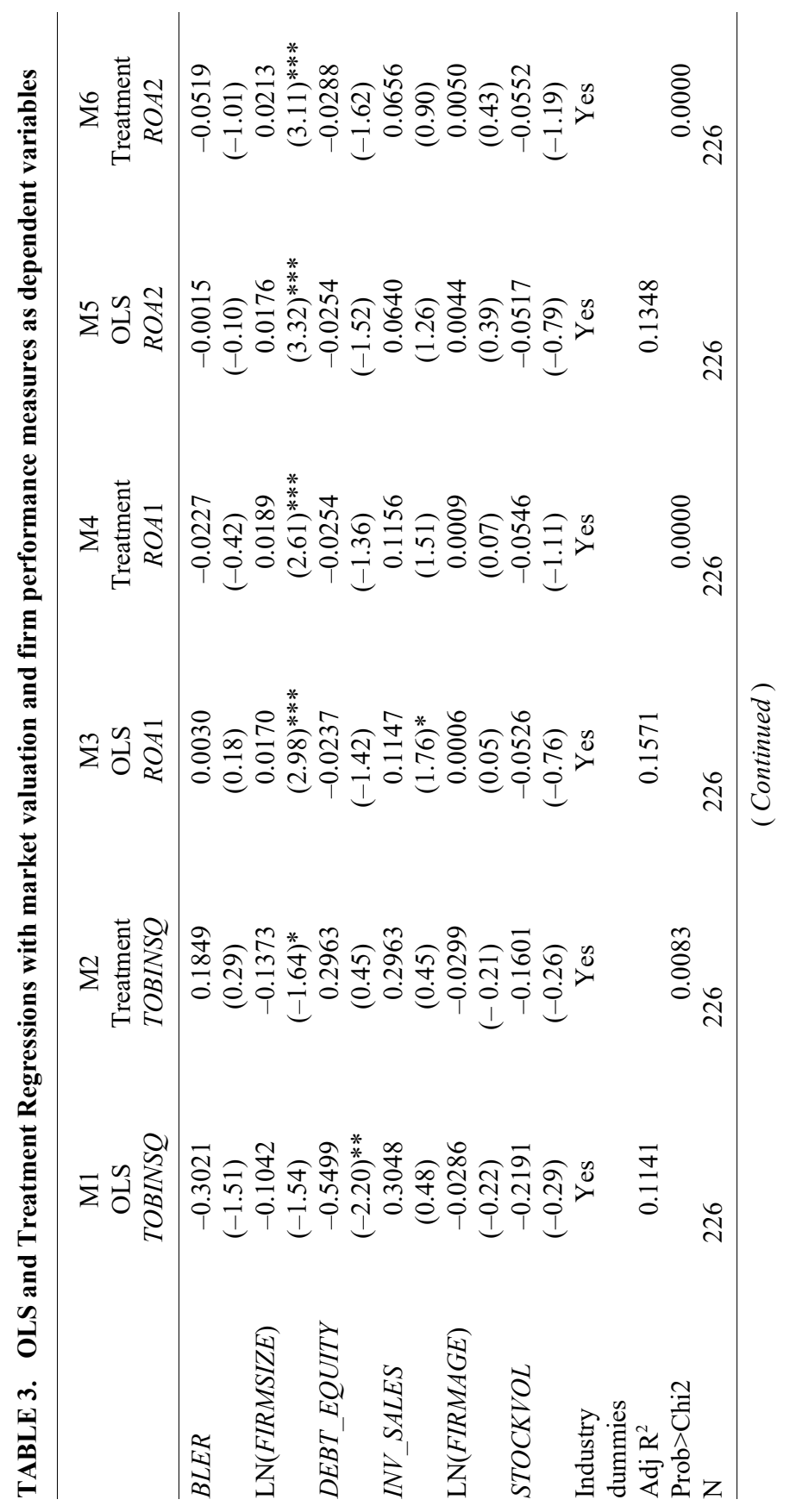




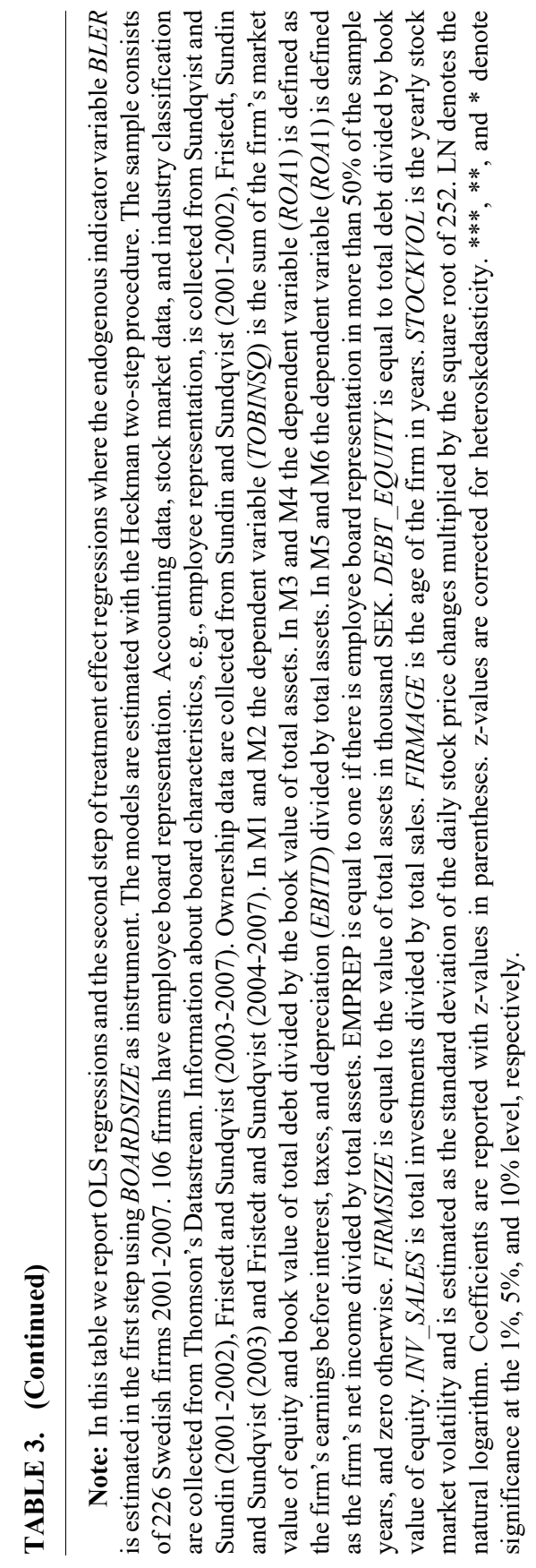


regression with $B L E R$ as dependent variable. We control for BOARDSIZE, VOTE_LARGEST, and the natural logarithm of FIRM_AGE. Thus, we estimate the following model:

$$
\begin{aligned}
\operatorname{Pr}(\text { BLER }=1)_{i}= & \alpha+\beta_{1} \text { EMPLOYEES } 1000 \\
& +\beta_{2} \text { EMPLOYEES1000_SQUARED }_{i} \\
& +\beta_{4} \ln \left(\text { BOARDSIZE }_{i}\right)+\beta_{5} \text { VOTE_LARGEST }_{i} \\
& +\beta_{6} \ln (\text { FIRM_AGE })_{i}+\sum_{j=1}^{9} \gamma_{j} \text { Industry }_{j}+\varepsilon_{i}
\end{aligned}
$$

Table 4 reports the results. In the first model we only include the number of employees expressed in thousands (EMPLOYEES1000) and this variable is positively significant at the one percent level. In model 2 we include the squared term of EMPLOYEES1000. EMPLOYEES1000 is still positively significant and the squared term is negatively significant at the one percent level. Thus, the relation between number of employees and BLER is indeed positive and non-linear.

The significant relation between $B L E R$ and number of employees might of course only be a size effect. In model 3 we replace number of employees with the natural logarithm of the value of the firm's total assets (FIRMSIZE). The likelihood of BLER increases significantly with FIRMSIZE. However, when both number of employees and firm size are included in model 4 , only number of employees and its squared term are significant, while firm size is insignificant. It appears that it is the number of employees that increases the likelihood of $B L E R$, not firm size measured as the value of total assets.

Consistent with the argument that shareholders increase board size in order to limit the employees' influence in cases where employees exercise their option to be on the board, employee board representation is indeed positively and significantly related to board size. The likelihood of $B L E R$ also increases with firm age. A large controlling shareholder (VOTE_LARGEST) does not appear to be related to the likelihood of BLER.

We now turn to our second hypothesis that the likelihood of $B L E R$ should decrease with firm characteristics that make it less attractive for employees to sit on the board, and vice versa. In model 5 we include a proxy for firm risk, i.e., the firm's stock market volatility (STOCKVOL), 
and this variable is negatively significant. Our second proxy for increased risk, volatility in the number of employees (EMPVOL), is included in model 6. It is negatively significant at the 10 percent level. The firm age result can also be interpreted in terms of firm risk and hypothesis 2 . Older firms are likely to operate in more stable business environments, other things equal.

Our next variable capturing the employee's cost-benefit analysis is sales growth (SALES_GR). An employee's costs (benefits) of sitting on the board should decrease (increase) in a firm that is growing more rapidly, ceteris paribus. However, SALES_GR is insignificant in model 7. In model 8 we include our proxy for foreign operations, a dummy variable equal to one if the firm has at least one foreign board member (FOREIGN_BOARD). Our hypothesis is that foreign operations make board work more demanding. The coefficient on FOREIGN_BOARD is negatively significant, while the number of employee results remain roughly unchanged. Foreign board members most likely correlate with more foreign employees. Thus, the foreign board members result might also be driven by fewer eligible domestic employees.

In model 9 we include all our four proxies for the cost-benefit analysis. All four variables are then significant (SALES_GR at the ten percent level). Thus, it appears that stock market volatility, employee volatility, sales growth, and foreign board members capture different aspects of an employee's costs and benefits of sitting on the board. Furthermore, EMPLOYEE 1000 and its squared term are more or less unaffected by adding these variables to the model, indicating that the number of employees effect is separate from the cost-benefit effects.

Variance inflation factors (VIF) suggest that we potentially have multicollinearity problems (VIF $>10$ ) in some of the reported models in table 4. The multicollinearity problems stem from the correlation between firm age, board size, firm size, and number of employees. If we drop firm age and/or board size from the regressions, multicollinearity is significantly reduced (all $\mathrm{VIFs}<10$ ) and the main results remain unchanged.

\section{Additional Results and Robustness Tests}

We have documented that $B L E R$ appears to be unrelated to firm performance in Sweden. However, BLER could be related to board actions such as executive pay and firing management. We explore these issues below.

We use annual reports to collect data on CEO compensation and 


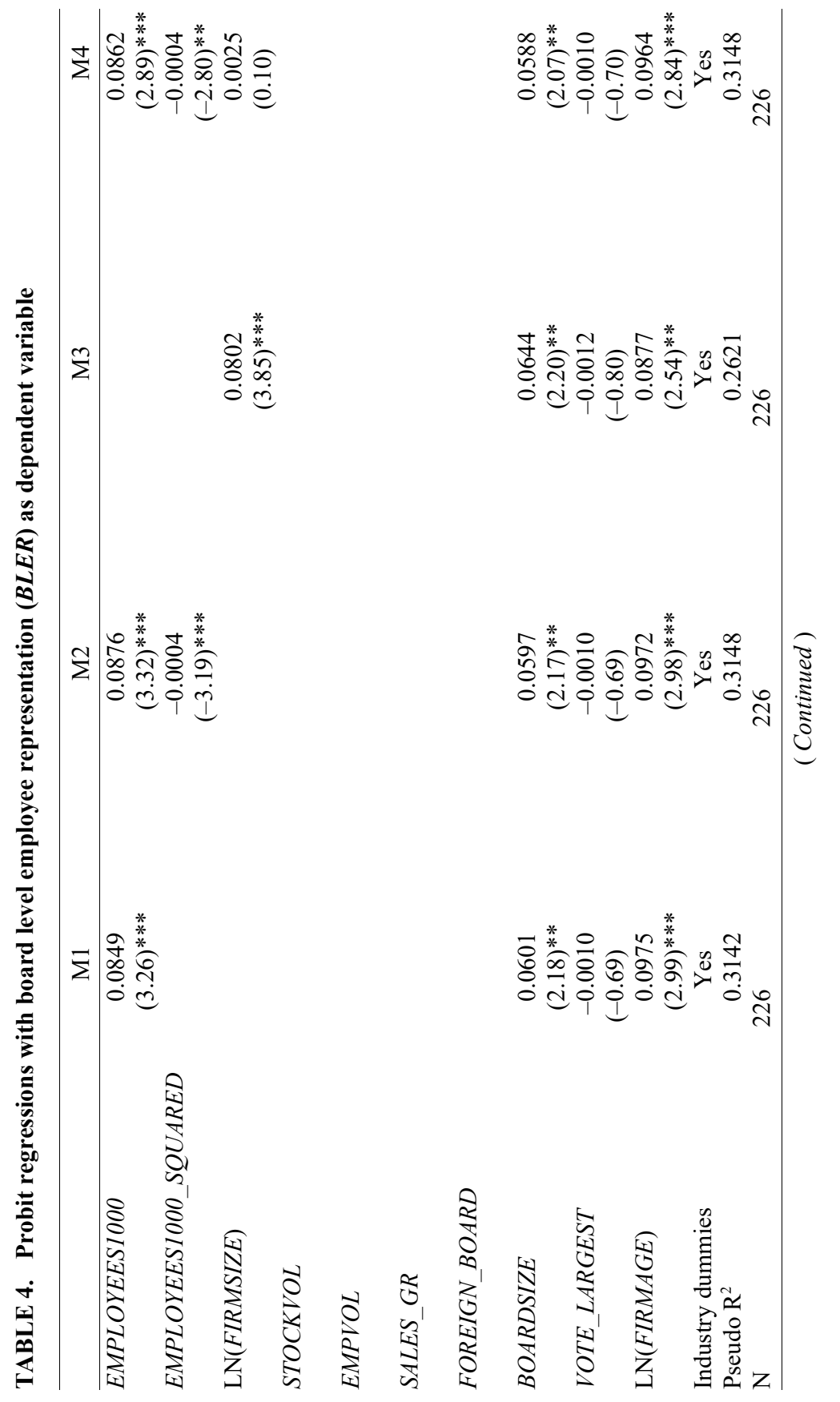




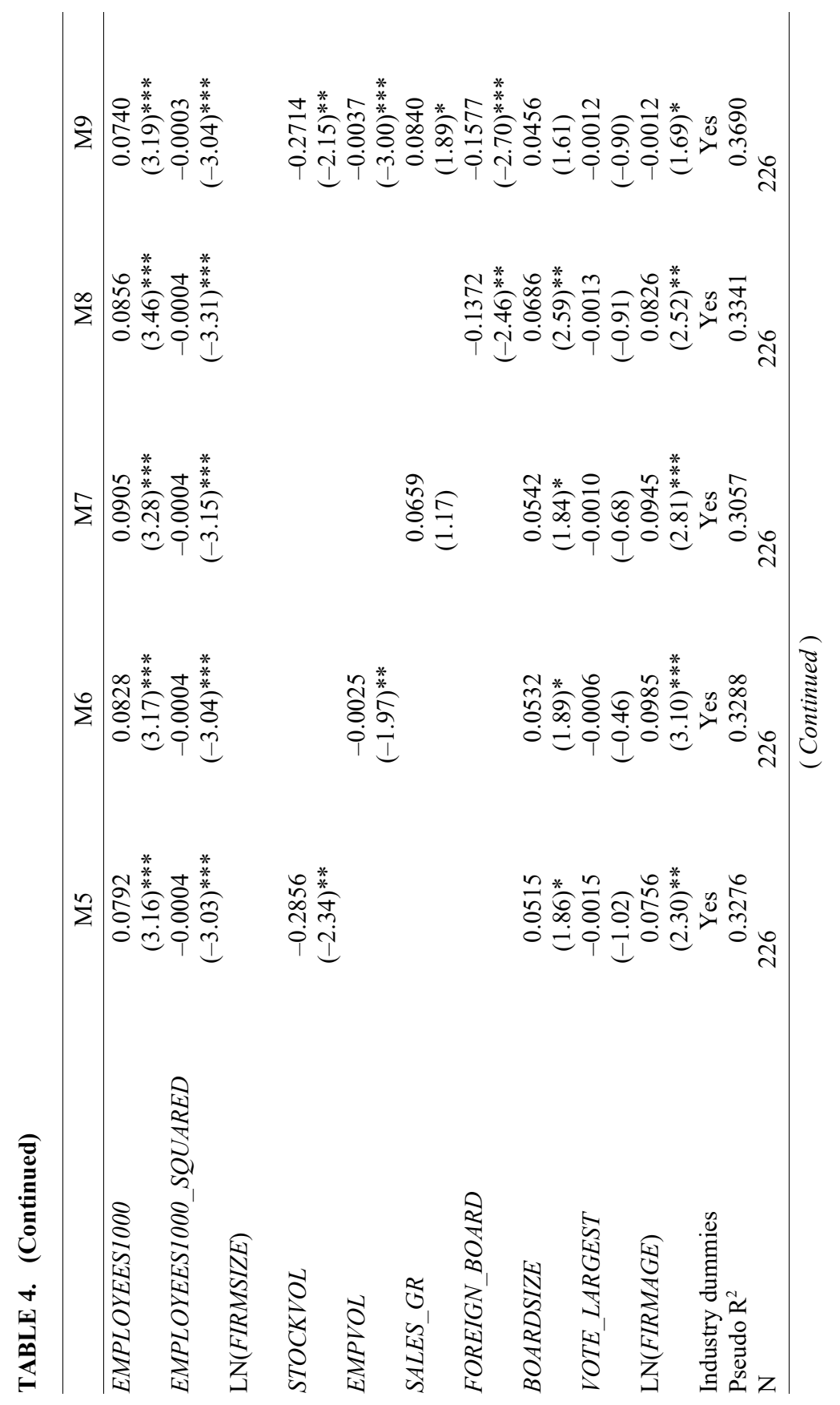




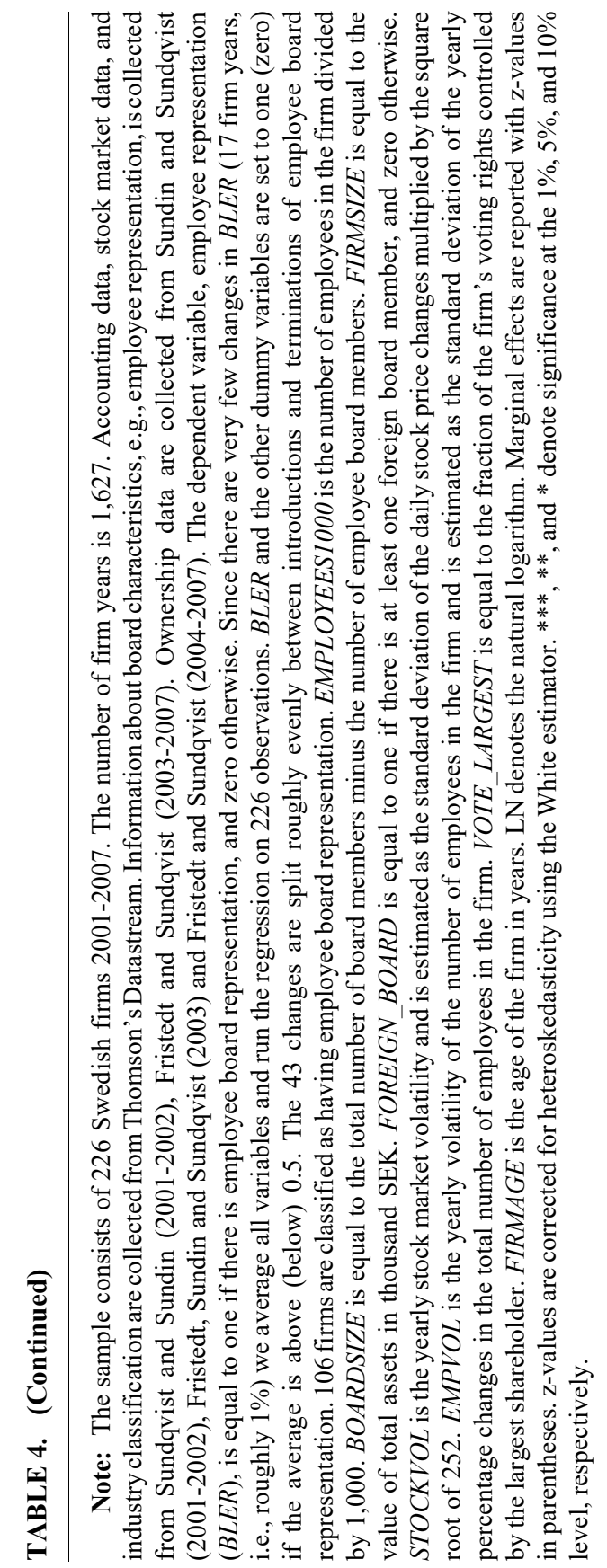


CEO changes from annual reports. As the information in the annual reports regarding executive stock options is incomplete, executive stock options are not part of the analysis. The average (median) CEO fixed pay is SEK 2.5 million (SEK 1.9 million). ${ }^{2}$ The average (median) bonus payment is SEK 0.8 million (SEK 0.3 million). The average (median) bonus/fixed pay ratio is $0.28(0.15)$. There are 259 CEO changes in our sample, which means that there is almost a 20 percent probability of a CEO change in each firm year, ceteris paribus.

We first estimate treatment effect models with executive pay as dependent variable. We use the same independent variables and instrument as in table 3 but add the fraction of voting rights controlled by the largest shareholder as an independent variable. This variable should capture monitoring effects. In table 5 we report that $B L E R$ is associated with higher salaries for CEOs. Both the fixed salary and the bonus component are higher in $B L E R$ firms. The ratio of bonus to fixed pay is however not different in $B L E R$ firms. The other variables are in line with previous literature, i.e., executive compensation increases (decreases) with firm size and risk (large controlling shareholders).

Higher cash compensation for the CEO per se is difficult to interpret. It could be due to stronger managerial power in BLER firms. It could also be a result of stronger tournament incentives for top managers in $B L E R$ firms. We therefore investigate whether higher CEO pay is related to stronger firm performance sensitivity of CEO dismissal, which would be consistent with stronger tournament incentives and inconsistent with the managerial power hypothesis.

Table 6 reports results relating to the firm performance-CEO dismissal sensitivity. Firm performance is measured by return on assets (ROA1) and CEO dismissal is equal to a CEO change. The variable of interest is the interaction term between $R O A 1$ and $B L E R\left(R O A 1^{*} B L E R\right)$, which measures whether CEO dismissal is more or less sensitive to firm performance in $B L E R$ firms. In order to capture the contemporaneous relation between performance and CEO changes, the data is not averaged over time. We report a probit model (1) and a random effect probit model (2). Dependent variables are firm size, age, risk (volatility), debt ratio, and investment ratio as well as the fraction of voting rights controlled by the largest shareholder, board size and a dummy for foreign board members.

2. The SEK/USD exchange rate was 7.2 in the middle of our sample period, i.e., in the beginning of 2004 . 
TABLE 5. Treatment regressions with executive compensation variables as dependent variables

\begin{tabular}{lccc}
\hline & M1 & M2 & M3 \\
& LN_FIXED_PAY & LN_BONUS & BONUS/FIXED_PAY \\
\hline BLER & 0.3119 & 0.4791 & 0.0709 \\
LN(FIRMSIZE $)$ & $(2.23)^{* *}$ & $(2.18)^{* *}$ & $(1.14)$ \\
& 0.2899 & 0.9845 & 0.0312 \\
DEBT_EQUITY & $(14.74)^{* * *}$ & $(3.30)^{* * *}$ & $(3.60)^{* * *}$ \\
& -0.0938 & 0.0519 & 0.0014 \\
INV_SALES & $(-1.86)^{*}$ & $(0.07)$ & $(0.06)$ \\
& -0.1978 & -0.2398 & -0.0386 \\
LN(FIRMAGE $)$ & $(-1.22)$ & $(0.34)$ & $(-0.54)$ \\
& -0.0236 & -0.0951 & -0.0098 \\
STOCKVOL & $(-0.71)$ & $(-0.19)$ & $(-0.68)$ \\
& 0.5126 & 0.7601 & -0.0679 \\
VOTE_LARGEST & $(3.49)^{* * *}$ & $(0.34)$ & $(-1.05)$ \\
Industry dummies & -0.0042 & -0.0576 & -0.0013 \\
Prob>Chi2 & $(-3.58)^{* * *}$ & $(-3.23)^{* * *}$ & $(-2.43)^{* *}$ \\
& Yes & Yes & Yes \\
N & 0.0000 & 0.0000 & 0.0000 \\
\hline
\end{tabular}

Note: In this table we report the second step of treatment effect regressions where the endogenous indicator variable BLER is estimated in the first step using BOARDSIZE as instrument. The models are estimated with the Heckman two-step procedure. The sample consists of 226 Swedish firms 2001-2007. 106 firms have employee board representation. Accounting data, stock market data, and industry classification are collected from Thomson's Datastream. Information about board characteristics, e.g., employee representation, is collected from Sundqvist and Sundin (2001-2002), Fristedt and Sundqvist (2003-2007). Ownership data are collected from Sundin and Sundqvist (2001-2002), Fristedt, Sundin and Sundqvist (2003) and Fristedt and Sundqvist (2004-2007). FIXED_PAY is the CEO's fixed salary in SEK. BONUS is the CEO's bonus payment in SEK. FIRMSIZE is equal to the value of total assets in thousand SEK. DEBT_EQUITY is equal to total debt divided by book value of equity. INV SALES is total investments divided by total sales. FIRMAGE is the age of the firm in years. STOCKVOL is the yearly stock market volatility and it is estimated as the standard deviation of the daily stock price changes multiplied by the square root of 252 . VOTE_LARGEST is equal to the fraction of the firm's voting rights controlled by the largest shareholder. LN denotes the natural logarithm. Coefficients are reported with z-values in parentheses. $\mathrm{z}$-values are corrected for heteroskedasticity. ***, **, and * denote significance at the $1 \%, 5 \%$, and $10 \%$ level, respectively.

A negative coefficient on $R O A 1$ is expected as it indicates that CEO dismissal is less likely when the firm is performing well and vice versa. The $R O A 1$ coefficient is indeed negative, yet insignificant. However, the interaction term $R O A 1^{*} B L E R$ is significantly negative, suggesting 
TABLE 6. Probit regressions with CEO dismissal as dependent variable

\begin{tabular}{lcc}
\hline & M1 & M2 \\
& Probit & Random Effect Probit \\
\hline ROA 1 & -0.0716 & -0.2789 \\
BLER & $(-1.22)$ & $(-1.13)$ \\
& -0.0114 & -0.0444 \\
ROA $1 \times$ BLER & $(-0.45)$ & $(-0.42)$ \\
& -0.2731 & -1.0637 \\
LN(FIRMSIZE $)$ & $(-2.56)^{* *}$ & $(-2.08)^{* *}$ \\
& 0.0006 & 0.0024 \\
DEBT_EQUITY & $(0.07)$ & $(0.06)$ \\
& 0.0193 & 0.0751 \\
INV_SALES & $(0.24)$ & $(0.22)$ \\
& -0.3831 & 1.4923 \\
LN $(F I R M A G E)$ & $(-1.27)$ & $(-1.17)$ \\
& -0.0331 & -0.1289 \\
STOCKVOL & $(-1.93)^{*}$ & $(-1.65)^{*}$ \\
VOTE_LARGEST & 0.0814 & 0.3171 \\
FOREIGN_BOARD & $(2.13)^{* *}$ & $(1.70)^{*}$ \\
BOARDSIZE & -0.0006 & -0.0023 \\
Industry dummies & $(-1.07)$ & $(-0.96)$ \\
N & 0.0396 & 0.1542 \\
\hline
\end{tabular}

Note: In this table we report Probit and Random Effect Probit models with change of CEO as dependent variable. The sample consists of 226 Swedish firms 2001-2007. Accounting data, stock market data, and industry classification are collected from Thomson's Datastream. Information about board characteristics, e.g., employee representation, is collected from Sundqvist and Sundin (2001-2002), Fristedt and Sundqvist (2003-2007). Ownership data are collected from Sundin and Sundqvist (2001-2002), Fristedt, Sundin and Sundqvist (2003) and Fristedt and Sundqvist (2004-2007). The dependent variable ( $C E O \_C H A N G E$ ) is equal to one if there is a new CEO compared to the year before, and zero otherwise. (ROA1) is defined as the firm's earnings before interest, taxes, and depreciation $(E B I T D)$ divided by total assets. Employee representation $(B L E R)$, is equal to one if there is employee board representation, and zero otherwise. FIRMSIZE is equal to the value of total assets in thousand SEK. DEBT_EQUITY is equal to total debt divided by book value of equity. INV SALES is total investments divided by total sales. FIRMAGE is the age of the firm in years. STOCKVOL is the yearly stock market volatility and it is estimated as the standard deviation of the daily stock price changes multiplied by the square root of 252 . VOTE_LARGEST is equal to the fraction of the firm's voting rights controlled by the largest shareholder. FOREIGN_BOARD is equal to one if there is at least one foreign board member, and zero otherwise. $B O \bar{A} R D S I Z E$ is equal to the total number of board members minus the number of employee board members. LN denotes the natural logarithm. Marginal effects are reported with $\mathrm{z}$-values in parentheses. Standard errors are clustered on firm level. ***, **, and * denote significance at the $1 \%, 5 \%$, and $10 \%$ level, respectively. 
that the performance-CEO dismissal sensitivity is significantly stronger in $B L E R$ firms. A stronger performance-CEO dismissal sensitivity is typically interpreted as an indication of good corporate governance (see, e.g., Weisbach, 1988). Thus, BLER does not appear to be related to deteriorating corporate governance. We interpret this result in terms of correlation and not a casual effect.

Admittedly, not all CEO changes are the result of forced dismissals. However, the probability of CEO changes in general is not different in $B L E R$ firms ( $B L E R$ per se is insignificant). Thus, we find it unlikely that our results are driven by a spurious correlation caused by a higher probability that CEOs voluntarily resign in non-BLER firms.

In unreported tests, we investigated some other potential effects of $B L E R$. First, we tested whether average salaries are higher in firms with $B L E R$. We did not find any indication of this. In fact, if anything, average salaries are lower in firms with $B L E R$. Second, we ran panel data fixed effect regressions to investigate whether the sensitivity of the number of employees is more or less sensitive to firm performance if employees are on the board. We find no differences between firms with employee board representation and firms without employee board representation.

In other unreported tests, we re-ran all the models in table 4 with $B L E R$ measured as the percentage of board size. The results are virtually unchanged except model 4 where firm size then becomes significant and the number of employees and its squared terms become insignificant.

In most of the reported results, we have averaged the data over 20012007. We argue that some of the independent variables contain less noise if we average them over time, e.g., stock market volatility, change in the number of employees, and sales growth. The number of employees per se is more stable. Indeed, when we run model 9 in table 4 year by year, the number of employee result is fairly robust while the other variables become insignificant in many of the yearly regressions.

Finally, even if we do not find a negative relation between $B L E R$ and firm performance, $B L E R$ could potentially harm performance indirectly through increased board size if shareholders require as many board seats as in the absence of $B L E R$, which appears to be the case. Larger boards have been found to be negatively related to firm performance and this has been interpreted as increased coordination and information problems in larger boards (see, e.g., Yermack, 1996).

We test for but do not find a negative relation between board size (including employee representatives) and firm performance (Tobin's q 
and $R O A$ ) in our sample using OLS and treatment effect models. We also tested for a non-linear relation between board size and firm performance, and the results were insignificant. Thus, it appears that board size is not detrimental to firm performance in Sweden, at least during our sample period. The difference between the U.S. and Sweden might be related to generally smaller boards in Sweden, i.e., few Swedish boards would be considered large by U.S. standards. The average board size, excluding employee representatives, in our sample is 6.42. In Yermack's (1996) sample, the average board size is almost twice at large at 12.25 .

\section{Conclusion and Discussion}

This paper first tested for a relation between $B L E R$ and firm performance. The results revealed no statistically significant relation. This is in line with the inconclusive evidence in earlier empirical studies. For example, Fauver and Fuerst (2006) and Ginglinger, Megginson, and Waxin (2011) find a positive relation between $B L E R$ and firm performance while, e.g., Gorton and Schmid (2004) and Bøhren and Strøm (2010) find a negative relation between BLER and performance.

Second, we explored a question that has not been addresses in earlier literature. Motivated by the observation that in roughly half of the Swedish firms where the employees have the right to nominate board members they choose not to do so, we developed and tested two hypotheses about the presence or absence of $B L E R$ in individual firms. The first hypothesis, that the likelihood of BLER is positively and non-linearly related to the number of employees in the firm, was strongly supported in the Swedish data. The second hypothesis was based on the argument that the likelihood of BLER decreases with firm characteristics that decrease employees' benefits of sitting on the board and/or that make board work more demanding. The results indicate that the likelihood of BLER indeed decreases with firm risk, slow growth, and internationalization. We conclude that employee board representation can at least to some extent be seen as the outcome of rational choice by employees eligible for board seats.

Finally, we extend the $B L E R$ literature by investigating the relation between $B L E R$ and CEO compensation and firm performance sensitivity of CEO-dismissal, respectively. We find that $B L E R$ is related to higher 
CEO pay in combination with stronger firm performance sensitivity of CEO-dismissal, which is in line with stronger tournament incentives among top managers in BLER firms. We conclude that BLER does not necessarily harm the corporate governance function of boards as argued by, e.g., Roe (2003; p. 75) and Jensen and Meckling (1979).

We believe the paper contributes to the BLER literature along at least three dimensions. First, Blair (1995 and 1998), Blair and Roe (1999), Osterloh and Frey (2006), and others argue that BLER might lead employees to invest in firm-specific human capital which benefits the firm. Similarly, Kanfer (1990) argues that BLER leads to more motivated employees. Our analysis is also related to employees investing in firm-specific human capital and motivation, but our focus is solely on the employees that choose (not) to serve as employee representatives on the board, and not on employees in general when $B L E R$ is in place.

Second, we find that in an environment where employees have the right to be represented on the board, this option might not be exercised. Since there should be some benefits from board representation, the tendency not to exercise the board representation option suggests that sitting on the board implies significant costs for the individual employee.

Third, our results suggest no significant relation between $B L E R$ and firm performance. Our interpretation of this result is that well-run firms take employee interests properly into account independently of whether the employees are represented on the board. Indeed, Swedish law contains a number of mandatory rules for how firms should take employee interests into account in addition to the BLER option. ${ }^{3}$ At the same time, having employee representatives on the board is unlikely to be a significant burden to the firm. This holds in particular for firms operating in a stable environment.

Whether the benefits of legally mandated $B L E R$ rights for employees, as in Sweden, are high enough to justify the additional administrative costs that $B L E R$ may cause in cases where the owners would prefer not to have employee representatives on the board is an open question. The mere fact that the $B L E R$ option is always present (in all but the smallest firms) may make management more sensitive to employee requests and thus reduce the likelihood of costly unexpected

3. See: Lag (1976:580) om medbestämmande i arbetslivet (co-determination act 1976:580, our translation). 
conflicts between management and employees. The advantages of this effect may well be strong enough to offset the costs incurred in a few cases where $B L E R$ is introduced against the employer's will.

Accepted by: Prof. D. Yermack, Guest Editor, November 2016

P.C. Andreou, PhD, Editor-in-Chief(Pro-Tem), November 2016

\section{References}

Anderson, R., and Reeb. D. 2003. Founding-family ownership and firm performance: Evidence from the S\&P 500. Journal of Finance 58(3): 13011327.

Baums, E., and Frick, B. 1999. The market value of codetermined firms. Chapter 7. In M. Blair and M. Roe (eds). Employees and Corporate Governance. Washington D.C.: The Brookings Institution.

Becht, M.; Bolton, P.; and Roell, A. 2003. Corporate governance and control. Chapter 1. In G. Constantinides, M. Harris, and R. Stulz (eds). Handbook of the Economics of Finance, Volume 1A. Amsterdam: North-Holland.

Blair, M. 1995. Ownership and Control. Rethinking Corporate Governance for the Twenty-First Century. Washington D.C.: The Brookings Institution.

Blair, M. 1998. For whom should the corporations be run? An economic rationale for stakeholder management. Long Range Planning 31(2): 195200.

Blair, M., and Roe, M. 1999. Employees and Corporate Governance. Washington D.C.: The Brookings Institution.

Böhren, Ö., and Ström, Ö. 2010. Governance and politics: Regulating independence and diversity in the board room. Journal of Business Finance and Accounting 37(9): 1281-1308.

Conchon, A. 2011. Board-level employee representation rights in Europe: Facts and trends. Etui report 121.

Fauver, L., and Fuerst. M. 2006. Does good corporate governance include employee representation? Evidence from German corporate boards. Journal of Financial Economics 82: 673-710.

Freeman, R., and Reed, D. 1983. Stockholders and stakeholders: A new perspective on corporate governance. California Management Review 25(3): 88-106.

Fristedt, D., and Sundqvist, S.-I. 2003-2007. Directors and Auditors in Sweden's Largest Companies. Dagens Nyheter, Stockholm.

Fristedt, D.; Sundin, A.; and Sundqvist, S.-I. 2003. Owners and Power in Sweden's Listed Companies. Dagens Nyheter, Stockholm.

Fristedt, D., and Sundqvist, S.-I. 2004-2007. Owners and Power in Sweden's Listed Companies. Dagens Nyheter, Stockholm. 
Garcia-Castro, R., and Aguilera, R. 2015. Incremental value creation and appropriation in a world with multiple stakeholders. Strategic Management Journal 36: 137-147.

Garcia-Castro, R.; Arino, M.; and Canela, M. 2010. Does social performance really lead to financial performance? Accounting for endogeneity. Journal of Business Ethics 92: 107-126.

Ginglinger, E., Megginson, W., and Waxin, T. 2011. Employee ownership, board representation, and corporate financial policies. Journal of Corporate Finance 17(4): 868-887.

Gorton, G., and Schmid, F. 2004. Capital, labor, and the firm: A study of German codetermination. Journal of the European Economic Association 2(5): 863-905.

Gregoric, A.; Rapp, M.; Sinani, E.; and Wolff, M. 2013. Sharing voice with the employees: Implications for firm behavior and performance during the recent crisis. Working Paper Copenhagen Business School.

Högfeldt, P. 2005. The History and Politics of Corporate Ownership in Sweden. In: R. Morck (ed). A History of Corporate Governance around the World: Family Business Groups to Professional Managers. NBER, University of Chicago Press.

Jackson, G. 2005. Employee Representation in the Board Compared: A Fuzzy Sets Analysis of Corporate Governance, Unionism and Political Institutions. Industrielle Beziehungen 12(3): 252-279.

Jensen, M., and Meckling, W. 1979. Rights and production functions: An application to labor-managed firms and codetermination. Journal of Business 52(4): 469-506.

Kanfer, R. 1990. Motivation theory and industrial/ organizational psychology. In M. Dunnette and L. Hough (Eds), Handbook of Industrial and Organizational Psychology. Volume 1. Theory in Industrial and Organizational Psychology. Palo Alto, CA: Consulting Psychologist Press.

Lekvall P.; Gilson, R.; Lau Hansen, J.; Lønfeldt, C.; Airaksinen, M.; Berglund, T.; Weymarn, T.; Knudsen, G.; Norvik, H.; Skog R.; and Sjöman E. 2014. The Nordic Corporate Governance Model. Stockholm: SNS Förlag.

Levine D., and Tyson, L. 1990. Participation, Productivity, and the Firm's Environment. In A. Blinder (ed). Paying for Productivity: A Look at the Evidence. Washington, D.C.: The Brookings Institution.

Levinson, K. 2001. Employee representatives on company boards in Sweden. Industrial Relations Journal 32(3): 264-274.

Osterloh, M., and Frey, B. 2006. Shareholders should welcome knowledge workers as directors. Journal of Management and Governance 10(3): 325345.

Roe, M. 2003. Political Determinants of Corporate Governance: Political Context, Corporate Impact. Oxford University Press.

Sjöstrand S.; Berglund, T.; Grönberg, L; Kallifatides, M.; Poulfelt, F.; Pöyry, S.; and Sigurjonsson. O. 2016. Nordic Corporate Governance; An in-depth 
study of governance and board practices in 36 large companies, Stockholm, SSE Institute for Research.

Sundin, A., and Sundqvist, S.-I. 2001-2002, Directors and auditors in Sweden's largest companies. Dagens Nyheter, Stockholm.

Sundin, A., and Sundqvist, S.-I. 2001-2002. Owners and Power in Sweden's Listed Companies. Dagens Nyheter, Stockholm.

Thomsen, S.; Rose, C.; and Kronborg. D. 2016. Employee Representation and Board Size in the Nordic Countries, European Journal of Law and Economics, 42(3): 471-490.

Villalonga B., and Amit, R. 2006. How do family ownership, control and management affect firm value? Journal of Financial Economics 80: 385417.

White, H. 1980. A heteroskedasticity-consistent covariance matrix estimator and a direct test for heteroskedasticity. Econometrica 48(4): 817-838.

Yermack, D. 1996. Higher Market Valuations of Companies with a Small Board of Directors. Journal of Financial Economics 40: 185-212.

Weisbach, M. 1988. Outside directors and CEO turnover. Journal of Financial Economics 20: 431-460. 